\section{Physiological Response of Mature Green Tomatoes to Treatment with Ethylene at High Temperature}

\author{
Francisco E. Loayza ${ }^{1}$, Michael T. Masarirambi ${ }^{1}$, Jeffrey K. Brecht ${ }^{1}$, \\ Steven A. Sargent ${ }^{1}$, and Charles A. Sims ${ }^{2}$
}

Additional Index words. ACC oxidase, color, ethylene synthesis, heat stress, ripening, Solanum lycopersicum

SUMMARY. This study investigated the effect of ethylene treatment at high temperatures of 30 to $40{ }^{\circ} \mathrm{C}$ for up to 72 hours on subsequent ripening-associated processes in mature green 'Sunny' and 'Agriset 761' tomatoes (Solanum lycopersicum). Compared with ethylene-treated fruit at $20^{\circ} \mathrm{C}$, ethylene exposure at 30 or $35^{\circ} \mathrm{C}$ stimulated ripening in terms of ethylene biosynthesis and color development, but the ethylene effect was only apparent after transfer to air at $20^{\circ} \mathrm{C}$. There were no negative effects on ripe tomato quality related to ethylene exposure at 30 or $35{ }^{\circ} \mathrm{C}$. However, ethylene production of tomatoes was permanently impaired by ethylene exposure at $40^{\circ} \mathrm{C}$ for 48 or 72 hours even after transferring fruit to air at $20^{\circ} \mathrm{C}$; these fruit exhibited slow softening and color development. Our results suggest that tomatoes perceive ethylene at 30 to $35{ }^{\circ} \mathrm{C}$ despite impairment of ripening at those temperatures, with the accelerated ripening response becoming apparent only after transferring the tomatoes to air at lower temperature.

$\mathrm{F}$ lorida is one of the main fresh tomato (Solanum lycopersicum) growing regions in the United States where tomatoes are harvested almost year around, including during some summer months (Freeman et al., 2019). The standard agricultural practices for harvest, handling, and storage of tomatoes in Florida according to Zhou et al. (2014) include harvesting fruit at the mature-green (MG) stage of development and transporting them in bins or gondolas to packinghouses. The tomatoes are dumped in tanks of water for gentle transfer onto the packingline. The dump tank water is chlorinated and maintained at $10{ }^{\circ} \mathrm{F}$ above the fruit temperature to avoid cross-contamination and infiltration of water into the fruit. Subsequently, water rinsing, waxing, sorting, grading, carton filling, and palletization are done. At this point,

Received for publication 23 June 2020. Accepted for publication 2 Oct. 2020

Published online 30 October 2020

${ }^{1}$ Horticultural Sciences Department, University of Florida, 2550 Hull Road, Gainesville, FL 32611

${ }^{2}$ Food Science and Human Nutrition Department, University of Florida, 572 Newel Drive, Gainesville, FL 32611

J.K.B. is the corresponding author. E-mail: jkbrecht@ ufl.edu.

This is an open access article distributed under the CC BY-NC-ND license (https://creativecommons.org/ licenses/by-nc-nd/4.0/).

https://doi.org/10.21273/HORTTECH04668-20 without any previous cooling operation, tomatoes are loaded into ripening rooms at $\approx 20^{\circ} \mathrm{C}$ where the fruit slowly cool while being treated with exogenous ethylene (24-48 h at $100 \mathrm{ppm}$ ) to promote and synchronize ripening.

However, farmers face significant environmental challenges; for example, in Hillsborough County, one of the most important tomatoproducing counties in Florida, temperatures ranged between 28 and $33{ }^{\circ} \mathrm{C}$ on typical summer days of 2019 (National Oceanic and Atmospheric Administration, 2020). Under this climatic condition, tomatoes are most likely to be exposed to high temperatures in the field and hence during harvest. Thus, this is a problematic situation because exposure of $\mathrm{MG}$ tomatoes to temperatures greater than $30^{\circ} \mathrm{C}$ is well known to attenuate many aspects of ripening; for example, it has been reported that such high temperatures disrupt ripening as evidenced by poor color development (Maezawa et al., 1993; Picton and Grierson, 1988), delayed softening (Mitcham and McDonald, 1992; Mohammed et al., 1996), perturbed respiration rate (Cheng et al., 1988; Inaba and Chachin, 1989), and suppression of ethylene production (AttaAly, 1992). Furthermore, Yang et al. (1990) observed that tomatoes did not appear to respond to ethylene when fruit were incubated at high temperature, although Iwahashi et al. (1999) and Polenta et al. (2006) indicated that tomatoes completed ripening when transferred to lower temperature after a prestorage treatment at high temperature. Furthermore, it has been shown that high-temperature treatment of tomatoes can confer resistance to chilling injury (Lurie et al., 1997).

Considering this physiological behavior, we hypothesize that the application of ethylene to MG tomatoes while they are at the high field temperatures could still induce the normal onset and progression of ripening after those fruit are transferred to $20{ }^{\circ} \mathrm{C}$, which is considered to be the optimal ripening temperature (Sargent and Moretti, 2016). Therefore, the objective of this study was to investigate whether MG tomatoes are capable of responding to exogenous ethylene applied while the fruit are at high temperatures as occurs under commercial conditions, inducing the onset of fruit ripening and continuation of ripening without delays upon transfer to lower temperature.

\section{Materials and methods}

Plant material. Large size (U.S. Department of Agriculture, 1991) MG tomatoes of the cultivars Agriset 761, Sunbeam, and Sunny were obtained from a commercial

\begin{tabular}{llll}
\hline $\begin{array}{l}\text { Units } \\
\text { To convert U.S. to SI, } \\
\text { multiply by }\end{array}$ & U.S. unit & SI unit & $\begin{array}{l}\text { To convert SI to U.S., } \\
\text { multiply by }\end{array}$ \\
\hline 29.5735 & $\mathrm{fl} \mathrm{oz}$ & $\mathrm{mL}$ & 0.0338 \\
3.7854 & gal & $\mathrm{L}$ & 0.2642 \\
25.4 & inch(es) & $\mathrm{mm}$ & 0.0394 \\
0.1333 & $\mathrm{~mm}$ mercury & $\mathrm{kPa}$ & 7.5006 \\
0.4536 & $\mathrm{lb}$ & $\mathrm{kg}$ & 2.2046 \\
1 & $\mathrm{ppm}$ & $\mathrm{nL} \cdot \mathrm{g}^{-1}$ & 1 \\
1 & $\mathrm{ppm}$ & $\mu \mathrm{L} \cdot \mathrm{kg}^{-1}$ & 1 \\
1 & $\mathrm{ppm}$ & $\mu \mathrm{L} \cdot \mathrm{L}^{-1}$ & 1 \\
$\left({ }^{\circ} \mathrm{F}-32\right) \div 1.8$ & ${ }^{\circ} \mathrm{F}$ & ${ }^{\circ} \mathrm{C}$ & $\left({ }^{\circ} \mathrm{C} \times 1.8\right)+32$ \\
$\left({ }^{\circ} \mathrm{F} \div 1.8\right)+255.37$ & ${ }^{\circ} \mathrm{F}$ & $\mathrm{K}$ & $(\mathrm{K}-255.37) \times 1.8$
\end{tabular}


packinghouse in Ruskin, FL; from University of Florida North Florida Research and Education Center in Quincy, FL; or commercial farms in Quincy, FL. 'Sunbeam' was used for a preliminary experiment comparing air and ethylene treatment at 20 vs. $35{ }^{\circ} \mathrm{C}$. Subsequently, 'Sunny' and 'Agriset 761' tomatoes were used for experiments involving ethylene treatment at temperatures from 20 to $40{ }^{\circ} \mathrm{C}$. Fruit were transported to Gainesville where they were washed in $100 \mathrm{ppm}$ chlorine solution at $\mathrm{pH}$ 7.0 , rinsed, dried, and sorted. During sorting, fruit that showed red color development or that were misshapen or wounded were discarded.

EXPERIMENTAL PROCEDURE. Tomatoes (90 units) were evenly placed in three chambers per treatment. Every group of three chambers was located inside controlled temperature rooms. A gas mixing system with needle valve flowmeters supplied air and ethylene from compressed gas cylinders to gas mixing manifolds at equal pressure. After the gas mixture was bubbled through jars of water for humidification, it was sent inside the chambers with fruit. Once the air or ethylene treatments were completed, the tomatoes were transferred to air in a room at $20{ }^{\circ} \mathrm{C}$ and $95 \%$ relative humidity (RH) for ripening.

The first experiment was performed in June 1994. In this experiment, 'Sunbeam' tomatoes inside three chambers were treated with air (control) or $100 \mathrm{ppm}$ ethylene at $20^{\circ} \mathrm{C}$ (control) or $35^{\circ} \mathrm{C}$. In the second experiment, 'Sunny' and 'Agriset 761' tomatoes were treated with $100 \mathrm{ppm}$ ethylene at the control temperature of $20^{\circ} \mathrm{C}$ or at $25,30,35$, or $40^{\circ} \mathrm{C}$ for 24 , 48 , or $72 \mathrm{~h}$, all with $\approx 95 \% \mathrm{RH}$. After treatment, fruit were stored in air at $20{ }^{\circ} \mathrm{C}$ for up to $11 \mathrm{~d}$. This experiment was repeated twice for 'Sunny' tomatoes. One repetition was used for color and physiological analyses in Sept. 1994. The second repetition was used for determination of softening and internal composition in May 1995. In the case of 'Agriset 761' tomatoes, one repetition was performed for color evaluation in Oct. 1995.

Respiration AND ETHYLENE PRODUCTION. Respiration and ethylene production were measured by separating each set of 30 tomatoes into three samples of 10 tomatoes, with each sample enclosed in a 2 -gal jar for $1 \mathrm{~h}$. For respiration, a l-mL sample of headspace gas was taken through a serum cap from the jars containing the tomatoes. Then a 0.5 $\mathrm{mL}$ aliquot of the sample was injected into a gas chromatograph (GC). The GC (series 580 GC; GOW-MAC Instrument, Bethlehem, PA) was equipped with a thermal conductivity detector (TCD), and a $40.0 \times 0.125$-inch $80 /$ 100-mesh column (Porapak Q; Agilent Technologies, Santa Clara, CA). The injector and detector temperatures were set at $90{ }^{\circ} \mathrm{C}$ and the column at $40{ }^{\circ} \mathrm{C}$. Carrier gas was helium. The respiration rates were expressed as milliliters of carbon dioxide per kilogram fresh weight per hour.

For ethylene, $0.5 \mathrm{~mL}$ of a $1-\mathrm{mL}$ sample of headspace gas was injected at ambient temperature $\left(23^{\circ} \mathrm{C}\right)$ into a portable GC (Photovac 10A10; Perkin Elmer, Waltham, MA). The GC was equipped with a photo-ionization detector (PID), and a $30.0 \times$ 0.125 -inch $80 / 100$-mesh activatedalumina column. Carrier gas was nitrogen at $15 \mathrm{~mL} \cdot \mathrm{min}^{-1}$. The ethylene production rates were expressed as microliters per kilogram per hour on a fresh weight basis.

1 - AMINOCYCLOPROPANE - 1 CARBOXYLIC ACID OXIDASE ACTIVITY. 1-aminocyclopropane-1-carboxylic acid (ACC) oxidase (ACO) activity was measured in vivo at $23{ }^{\circ} \mathrm{C}$ using the method of Hoffman and Yang (1982), in which tomato pericarp tissue plugs were removed using a No. 6 cork borer ( $12 \mathrm{~mm}$ diameter) that was inserted radially into a fruit over a locule. Four plugs per fruit were collected from four fruit that sampled per treatment. The four plugs per fruit were put into a $18 \times$ $150-\mathrm{mm}$ test tube containing 2.0 $\mathrm{mL}$ of a $2.0 \%$ potassium chloride, $1.0 \mathrm{~mm}$ ACC, $1.0 \mathrm{~mm}$ aminooxyacetic acid solution, previously weighed and tared, and then the tissue weight was recorded. The test tubes with tissue plugs were attached to a vacuum evaporator/shaker (Evapomix; Buchler Instruments, Fort Lee, NJ), and a vacuum pressure of $15 \mathrm{~mm}$ of mercury was applied for $60 \mathrm{~s}$. After releasing the vacuum, the four plugs per tube were reweighed and put into $50-\mathrm{mL}$ flasks, and the headspace was flushed with air free of ethylene and then closed with a rubber septum cap for $60 \mathrm{~min}$. After $60 \mathrm{~min}$, a $1-\mathrm{mL}$ sample of gas was taken from each flask, and then a $0.5-\mathrm{mL}$ aliquot of gas was injected into a GC (Photovac 10A10). ACO activity was expressed as ethylene production on fresh weight.

CoLOR. The external color of each 10 -fruit replicate per treatment was monitored daily. Three measurements were taken near the blossom end of each fruit (Hobson et al., 1983). Color was measured using the CIE $\mathrm{L}^{*} \mathrm{a}^{*} \mathrm{~b}^{*}$ scale and recorded as $\mathrm{L}^{*}, \mathrm{a}^{*}, \mathrm{~b}^{*}$ and hue using a chromameter (CR200; Minolta, Tokyo, Japan) with the following characteristics: an 8 -mm port, a $2^{\circ}$ observer angle, and D65 illuminant (daylight illumination equivalent to sunlight at $6500{ }^{\circ} \mathrm{K}$ ). Hue angle was calculated from the $\mathrm{a}^{*}$ and $b^{*}$ values $\left[h^{\circ}=\arctan \left(b^{*} / a^{*}\right)\right]$.

Flesh firmness. Firmness of fruit from each treatment was measured $12 \mathrm{~d}$ after harvest, which occurred 11,10 , or $9 \mathrm{~d}$ after treatment with air or ethylene for 24,48 , or 72 h, respectively. Flesh firmness of tomatoes was measured using a Cornell firmness tester (Hamson, 1952) as modified by Gull (1987). A single tomato fruit was placed on a stand under a $1.0-\mathrm{kg}$ weight, and the handle of the tester was lowered until contact with the fruit at the equator was achieved. The handle was then released completely, and compression was noted in millimeters after $5 \mathrm{~s}$. Each fruit was measured twice, on opposite sides.

Analyses of total soluble SOLIDS AND TITRATABLE ACIDITY. Fruit from each treatment was measured 12 d after harvest, which occurred 11,10 , or $9 \mathrm{~d}$ after treatment with air or ethylene for 24,48 , or $72 \mathrm{~h}$, respectively. Longitudinal wedges from 10 fruit replicates were taken from the median of each fruit, bagged, and stored at $-20{ }^{\circ} \mathrm{C}$ for later use. The wedges were blended in a commercial blender (Waring, New Hartford, CT). The blended tomato puree was centrifuged for $45 \mathrm{~min}$ at $650 g_{\mathrm{n}}$ in a swinging bucket rotor centrifuge (International Centrifuge; International Equipment, Boston, MA). After centrifugation, the supernatant was recovered and used to measure total soluble solids (TSS), $\mathrm{pH}$, and titratable acidity (TA).

Total soluble solids were measured with a digital refractometer (Abbe Mark II; Cambridge Instruments, Buffalo, NY). The $\mathrm{pH}$ was directly measured in the supernatant using a pH-meter (model 140; Corning Co., Corning, NY). TA was 
quantified as described in $\mathrm{AOAC}$ method 22.058 (AOAC International, 1995). Titration was done using an automatic titrimeter (model 381; Thermo Fisher Scientific, Waltham, MA).

Statistical analysis. The preliminary experiment was designed as a completely randomized design using the following as factors: ethylene, treatment temperature, and treatment duration. The main experiment studying the effect of high temperature during ethylene treatment was evaluated with a two-way analysis of variance (ANOVA) using treatment temperature and treatment duration as factors. The least significant difference was calculated with $P \leq 0.05$ using statistical software (SAS version 6.01; SAS Institute, Cary, NC).

\section{Results}

Respiration AND ETHYLENE PRODUCTION. In the first experiment, respiration of 'Sunbeam' fruit treated with ethylene at $20{ }^{\circ} \mathrm{C}$ was generally higher than fruit treated with ethylene at $35^{\circ} \mathrm{C}$ after transferring to air at $20{ }^{\circ} \mathrm{C}$ indicating that high temperature reduced the physiological metabolism of the fruit. However, there were fluctuations in the respiration rates during storage at $20^{\circ} \mathrm{C}$, disrupting any distinguishable significant difference (data not shown).

Our results showed that ethylene production by 'Sunny' fruit treated with ethylene at $20,25,30,35$, or $40{ }^{\circ} \mathrm{C}$ for $24 \mathrm{~h}$ reached a peak 6 or 7 $\mathrm{d}$ after transfer to air at $20{ }^{\circ} \mathrm{C}$ (i.e., during the last $2 \mathrm{~d}$ of the experiment) (Fig. 1A). Fruit previously treated with ethylene at $40^{\circ} \mathrm{C}$ for $24 \mathrm{~h}$ produced the highest amounts of ethylene $\left(>8.0 \mu \mathrm{L} \cdot \mathrm{kg}^{-1} \cdot \mathrm{h}^{-1}\right)$. Fruit treated with ethylene at any of the same five temperatures for $48 \mathrm{~h}$ reached the ethylene production peak between 3 and $5 \mathrm{~d}$ after fruit were transferred to air at $20^{\circ} \mathrm{C}$. Fruit treated with ethylene for $48 \mathrm{~h}$ at $35^{\circ} \mathrm{C}$ produced the largest amounts of ethylene (8.0 $\left.\mu \mathrm{L} \cdot \mathrm{kg}^{-1} \cdot \mathrm{h}^{-1}\right)$. Fruit treated with ethylene for $72 \mathrm{~h}$ reached the maximum ethylene production 2 or $3 \mathrm{~d}$ after fruit were transferred to air at $20^{\circ} \mathrm{C}$, except for fruit from $40{ }^{\circ} \mathrm{C}$, which peaked on $4 \mathrm{~d}$. Also, for fruit previously exposed to ethylene for $72 \mathrm{~h}$. Those fruit treated at $35^{\circ} \mathrm{C}$ produced the largest amounts of ethylene (11.0 $\left.\mu \mathrm{L} \cdot \mathrm{kg}^{-1} \cdot \mathrm{h}^{-1}\right)$. All treatments reached full ripeness by 6 or $7 \mathrm{~d}$ at $20^{\circ} \mathrm{C}$ when measurements were stopped.

Significant differences in ethylene production were observed in fruit previously treated with $100 \mathrm{ppm}$ of ethylene for 48 or $72 \mathrm{~h}$ during storage at $20^{\circ} \mathrm{C}$ (Fig. $1 \mathrm{~B}$ and $\mathrm{C}$ ); for example, ethylene production was higher in fruit exposed to ethylene at 30 or $35^{\circ} \mathrm{C}$ for 48 or $72 \mathrm{~h}$ compared with fruit exposed to ethylene at 20 or $40{ }^{\circ} \mathrm{C}$ for the same period of time, whereas prior exposure of fruit to ethylene at $25{ }^{\circ} \mathrm{C}$ resulted in an intermediate ethylene production rate (Fig. 1C). However, there were no significant differences in ethylene production among treatments exposed to ethylene at any temperature for $24 \mathrm{~h}$ (Fig. 1A). These observations were similar to those of the preliminary experiment with the cultivar Sunbeam in which ethylene production was initially higher in tomatoes treated at $20^{\circ} \mathrm{C}$ for $48 \mathrm{~h}$ than in fruit exposed to ethylene at $35^{\circ} \mathrm{C}$, persisting for up to $3 \mathrm{~d}$; subsequently, the tomatoes treated at $35{ }^{\circ} \mathrm{C}$ for $48 \mathrm{~h}$ produced more ethylene than fruit treated at $20{ }^{\circ} \mathrm{C}$ for the same duration, especially at the climacteric peak (unpublished data). We found that ethylene production was inhibited after 48 or $72 \mathrm{~h}$ at $40{ }^{\circ} \mathrm{C}$ but was stimulated by exposure to lower temperatures $\left(25\right.$ to $35^{\circ} \mathrm{C}$ ).

ACO ACTIVITy. 'Sunny' tomatoes treated with ethylene at $30{ }^{\circ} \mathrm{C}$ for 24 or $48 \mathrm{~h}$ had the highest ACO activity immediately after treatment followed by fruit exposed to ethylene at 25 or $35^{\circ} \mathrm{C}$ (Fig. $2 \mathrm{~A}$ and B). Also, ethylene treatment at $40{ }^{\circ} \mathrm{C}$ produced the lowest ACO activity for both exposure times of 24 and 48 h compared with all the other treatments. During the subsequent days in air storage at $20{ }^{\circ} \mathrm{C}$, ACO activity was similar among all treatments. In the case of ethylene treatment for $72 \mathrm{~h}$, our findings showed that there was no difference in ACO activity measured immediately after treatment between all the ethylene treatments, and there were erratic fluctuations in ACO activity during ripening.

Color. The transition from green to red of MG 'Sunny' and 'Agriset 761' tomato fruit, measured as the $a^{*}$ value, followed a typical sigmoidal curve. Temperature of the ethylene treatments for $48 \mathrm{~h}$ produced significant differences in the $a^{*}$ value (Fig. 3B-E). For example, 'Sunny' tomatoes treated with ethylene at $25{ }^{\circ} \mathrm{C}$ had the fastest color development followed in order by tomatoes treated at 30,35 , or $20^{\circ} \mathrm{C}$, whereas in 'Agriset 761' tomatoes, the ethylene treatment at $30^{\circ} \mathrm{C}$ produced the fastest red color development, followed in order by treatments at 25,20 , or $35{ }^{\circ} \mathrm{C}$. Furthermore, we observed two distinctive behaviors for 'Sunny' and 'Agriset 761' when fruit were exposed to ethylene for $72 \mathrm{~h}$ (Fig. 3C-F). In the case of 'Agriset 761 ' tomatoes, ethylene treatment at $30{ }^{\circ} \mathrm{C}$ for $72 \mathrm{~h}$ induced rapid red color formation after transfer to air at $20^{\circ} \mathrm{C}$ followed in order by fruit treated at 25 , 20 , or $35{ }^{\circ} \mathrm{C}$ for $72 \mathrm{~h}$ (even more obviously than treatments involving exposure to ethylene for $48 \mathrm{~h}$ ). For 'Sunny' fruit treated with ethylene at $20,25,30$, or $35^{\circ} \mathrm{C}$ for $72 \mathrm{~h}$, red color developed at similar rates after transfer to air at $20{ }^{\circ} \mathrm{C}$ regardless of the ethylene treatment temperature. We also noticed that tomatoes treated with ethylene at $40{ }^{\circ} \mathrm{C}$ consistently had the lowest red color formation for all the exposure durations in both cultivars, indicating some degree of impairment of the ripening that persisted after transfer to air at $20^{\circ} \mathrm{C}$, which was more noticeable in 'Agriset 761 ' than in 'Sunny'. There were no significant differences between treatments for $24 \mathrm{~h}$ in both cultivars (Fig. $3 \mathrm{~A}-\mathrm{D})$. All treated tomatoes reached full ripeness between 5 and $7 \mathrm{~d}$ for 'Sunny' and between 5 and $11 \mathrm{~d}$ for 'Agriset 761' when stored at $20^{\circ} \mathrm{C}$. We can also remark that ethylene treatment for $72 \mathrm{~h}$ accelerated tomato ripening, with fruit reaching full ripeness in $\mathbf{5}$ d compared with after 9 or $11 \mathrm{~d}$ for ethylene treatments lasting 24 or $48 \mathrm{~h}$, except for tomatoes exposed to ethylene at $40{ }^{\circ} \mathrm{C}$ for $48 \mathrm{~h}$. Overall, ethylene treatment at all temperatures promoted red color development after the fruit were transferred to the conducive ripening temperature of $20^{\circ} \mathrm{C}$ except for ethylene treatments at $40{ }^{\circ} \mathrm{C}$ for 48 or $72 \mathrm{~h}$, which significantly delayed color development in tomatoes.

FLESH FIRMNESS AND INTERNAL COMPOSITION. Firmness as compression of whole was significantly affected by the temperature of the ethylene treatment in 'Sunny' tomatoes, but duration of the treatment did not produce significant differences (Table 1). Moreover, fruit 

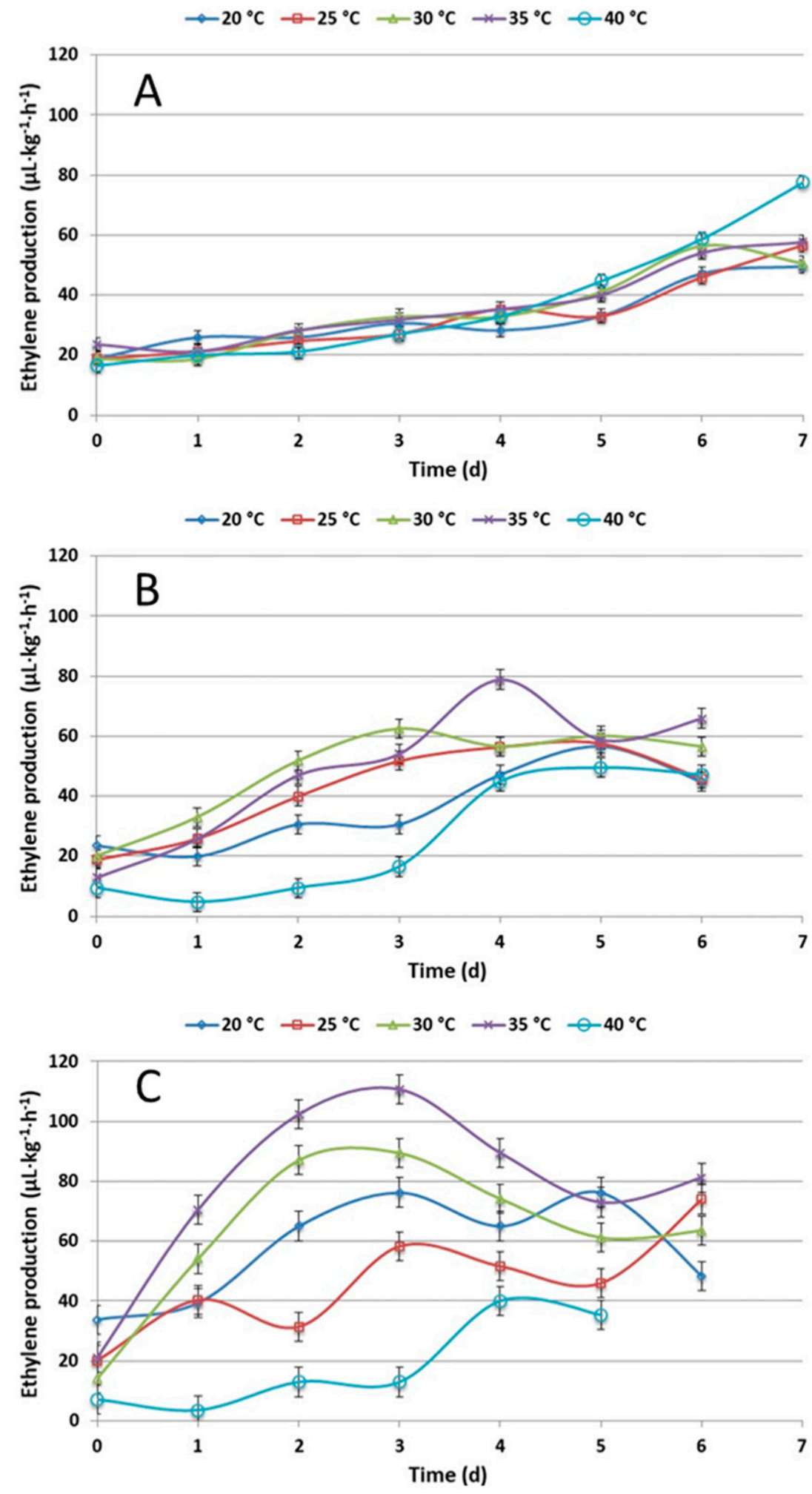

Fig. 1. Ethylene production of 'Sunny' tomatoes during storage at $20{ }^{\circ} \mathrm{C}$ after exposure to $100 \mathrm{ppm}\left(\mu \mathrm{L} \cdot \mathrm{L}^{-1}\right)$ ethylene at $20,25,30,35$, or $40{ }^{\circ} \mathrm{C}$ for $24 \mathrm{~h}(\mathrm{~A})$, $48 \mathrm{~h}(\mathrm{~B})$, or $72 \mathrm{~h}(\mathrm{C})$. Error bars represent the SE within treatments for each exposure time; $S E=\frac{s}{\sqrt{n}}$, where $s$ is the $S D$, and $n$ is the sample size; $\left(1.8 \times{ }^{\circ} \mathrm{C}\right)+32=$ ${ }^{\circ} \mathrm{F}, 1 \mu \mathrm{L} \cdot \mathrm{kg}^{-1}=1 \mathrm{ppm}$.

softening was more intense for fruit treated with ethylene at $30{ }^{\circ} \mathrm{C}$ for 48 or $72 \mathrm{~h}$, but less intense for fruit that were treated with ethylene at $40{ }^{\circ} \mathrm{C}$ for 48 or $72 \mathrm{~h}$ (Table 2 ). In other words, fruit treated with ethylene at $35^{\circ} \mathrm{C}$ for $72 \mathrm{~h}$ or at $40^{\circ} \mathrm{C}$ for 48 or 72 $\mathrm{h}$ had the firmest flesh compared with
20 or $30{ }^{\circ} \mathrm{C}$ for all other exposure times. However, we also observed that temperature did not produce a consistent pattern of softening in tomatoes treated with ethylene for $24 \mathrm{~h}$.

The $\mathrm{pH}$ was mainly affected by exposure time (Table 1); for example, tomatoes exposed to ethylene for 72 $\mathrm{h}$ had higher $\mathrm{pH}$ than fruit exposed to ethylene for $48 \mathrm{~h}$ followed by tomatoes exposed for $24 \mathrm{~h}$ (Table 2). Regarding the effect of temperature, fruit treated with ethylene at $20{ }^{\circ} \mathrm{C}$ tended to have higher $\mathrm{pH}$ for all exposure times, with the highest $\mathrm{pH}$ in tomatoes treated for $72 \mathrm{~h}(4.28)$. The lowest $\mathrm{pH}$ was observed in fruit treated with ethylene at $30^{\circ} \mathrm{C}$ for $48 \mathrm{~h}(3.93)$.

Despite the temperature and duration of exposure to ethylene causing significant differences in TA (Table 1), these differences were minimal among all ethylene treatments, although we must mention that tomatoes treated with ethylene at $30{ }^{\circ} \mathrm{C}$ had the highest TA $(1.36 \%)$, whereas all other treatment TA fluctuated between $0.99 \%$ and $1.10 \%$ (Table 2 ).

In terms of TSS, exposure time to ethylene decreased TSS in tomatoes; for instance, fruit treated with ethylene for $72 \mathrm{~h}$ had the lowest TSS values, followed by fruit treated for 48 $h$ and then 24 h. Furthermore, ethylene treatment temperature did not produce a distinctive trend for all treatment durations, although fruit exposed to ethylene at $30{ }^{\circ} \mathrm{C}$ for 48 $\mathrm{h}$ had the highest TSS (4.73\%) compared with all other temperature and time combinations (Table 2 ).

\section{Discussion}

The high fluctuations in the respiration rate of tomatoes is consistent with the findings of Cheng et al. (1988) and Inaba and Chachin (1989), who reported that high temperature exposure of MG tomatoes perturbed respiration rates, although it is also possible that this fluctuation is due to individual tomatoes being at different ripeness stages.

Few ripening differences were observed for fruit treated with ethylene for $24 \mathrm{~h}$ at the various temperatures, probably because 24 h was not long enough for the high temperatures $\left(\geq 30^{\circ} \mathrm{C}\right)$ to cause impairment in tomato physiology. In a separate experiment, it was observed that in our laboratory storage rooms, size large tomato fruit starting at $20^{\circ} \mathrm{C}$ required 

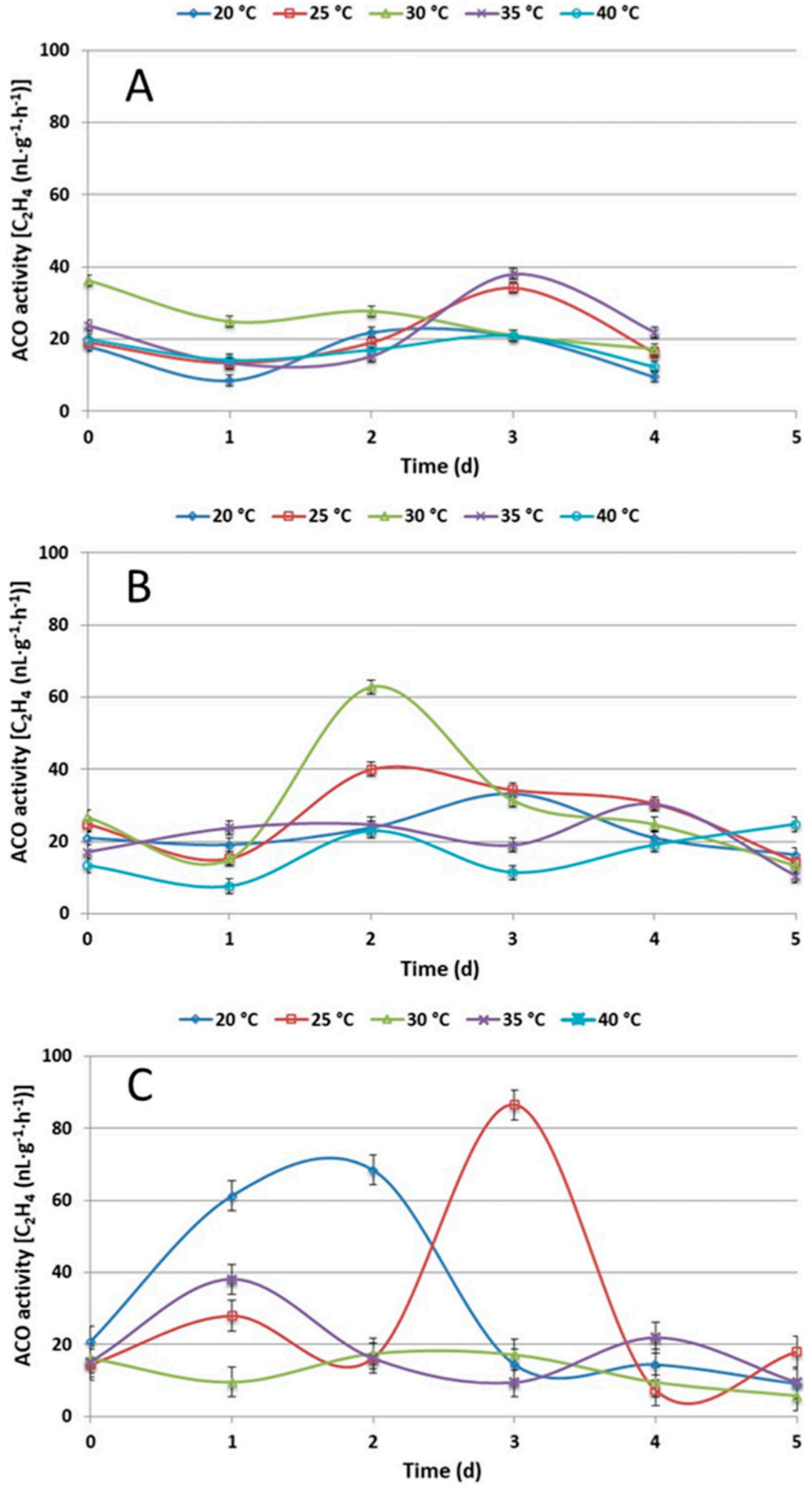

Fig. 2. The 1-aminocyclopropane-1-carboxylic acid oxidase (ACO) activity of 'Sunny' tomatoes during storage at $20{ }^{\circ} \mathrm{C}$ after exposure to $100 \mathrm{ppm}\left(\mu \mathrm{L} \cdot \mathrm{L}^{-1}\right)$ ethylene at $20,25,30,35$, or $40{ }^{\circ} \mathrm{C}$ for $24 \mathrm{~h}(\mathrm{~A}), 48 \mathrm{~h}(\mathrm{~B})$, or $72 \mathrm{~h}(\mathrm{C})$. ACO activity is expressed as ethylene $\left(\mathrm{C}_{2} \mathrm{H}_{4}\right)$ production per hour. Error bars represent the $\mathrm{SE}$ within treatments for each exposure time. $\mathrm{SE}=\frac{\mathrm{s}}{\sqrt{\mathrm{n}}}$, where $\mathrm{s}$ is the $\mathrm{SD}$, and $\mathrm{n}$ is the sample size; $\left(1.8 \times{ }^{\circ} \mathrm{C}\right)+32={ }^{\circ} \mathrm{F}, 1 \mathrm{~nL} \cdot \mathrm{g}^{-1}=1 \mathrm{ppm}$.

$11,12.5$, or 14 h to attain 30,35 , or $40{ }^{\circ} \mathrm{C}$, respectively, thus lessening the chances of high temperature impact within only 24-h exposure; in other words, we estimate that the effective treatment durations the current research were $13 \mathrm{~h}$ for the 24 -h treatments, $35.5 \mathrm{~h}$ for the 48 -h treatments, and $58 \mathrm{~h}$ for the 72 -h treatments.

'Sunny' fruit treated with ethylene at 30 or $35{ }^{\circ} \mathrm{C}$ for 48 or $72 \mathrm{~h}$ produced the largest amounts of ethylene, possibly because those temperatures are stressful and thus lead to additional ethylene production. Similarly, stress-induced ethylene production in tomato fruit has been reported by Botella et al. (2000), who found that preharvest salinity stress increased the accumulation of ACC and ethylene production and enhanced red color development.

It was remarkable that ethylene perception was apparently maximal at 30 to $35{ }^{\circ} \mathrm{C}$, and thus fruit treated with ethylene at those temperatures exhibited the maximum capacity for producing ethylene during subsequent ripening, as evidenced by the large amounts of ethylene produced after their transfer to $20^{\circ} \mathrm{C}$. Although a temperature of $35{ }^{\circ} \mathrm{C}$ has been reported to suppress tomato ethylene production (Atta-Aly, 1992; Cheng et al., 1988; Inaba and Chachin, 1989), those fruit were not treated with exogenous ethylene while at the high temperature. This is an indication that some downstream events in ethylene signal transduction may be affected by high temperature in a reversible manner. Furthermore, when Yang et al. (1990) added exogenous ethylene $(100 \mathrm{ppm})$ to the storage atmosphere of MG tomatoes to determine whether inhibition of ripening at high temperatures was due to reduced ethylene production or reduced sensitivity, they found that exogenous ethylene did not overcome inhibition of autocatalytic ethylene formation, color development, or softening during storage at 30 or $37^{\circ} \mathrm{C}$. However, as in other previous research, the fruit were not transferred to $20^{\circ} \mathrm{C}$. Therefore, unlike the research in the present report, the capability of the fruit to recover their ripening metabolism was never evaluated.

In addition, the least amount of ethylene was produced by fruit previously treated with ethylene at $40^{\circ} \mathrm{C}$ for 48 or $72 \mathrm{~h}$, apparently because $40^{\circ} \mathrm{C}$ is an extreme high temperature, and exposure to that temperature for 48 or $72 \mathrm{~h}$ led to inhibition of ethylene receptors or to irreversible damage of the fruit tissues. This is consistent with the findings of Cheng et al. (1988). In other research, we found that 

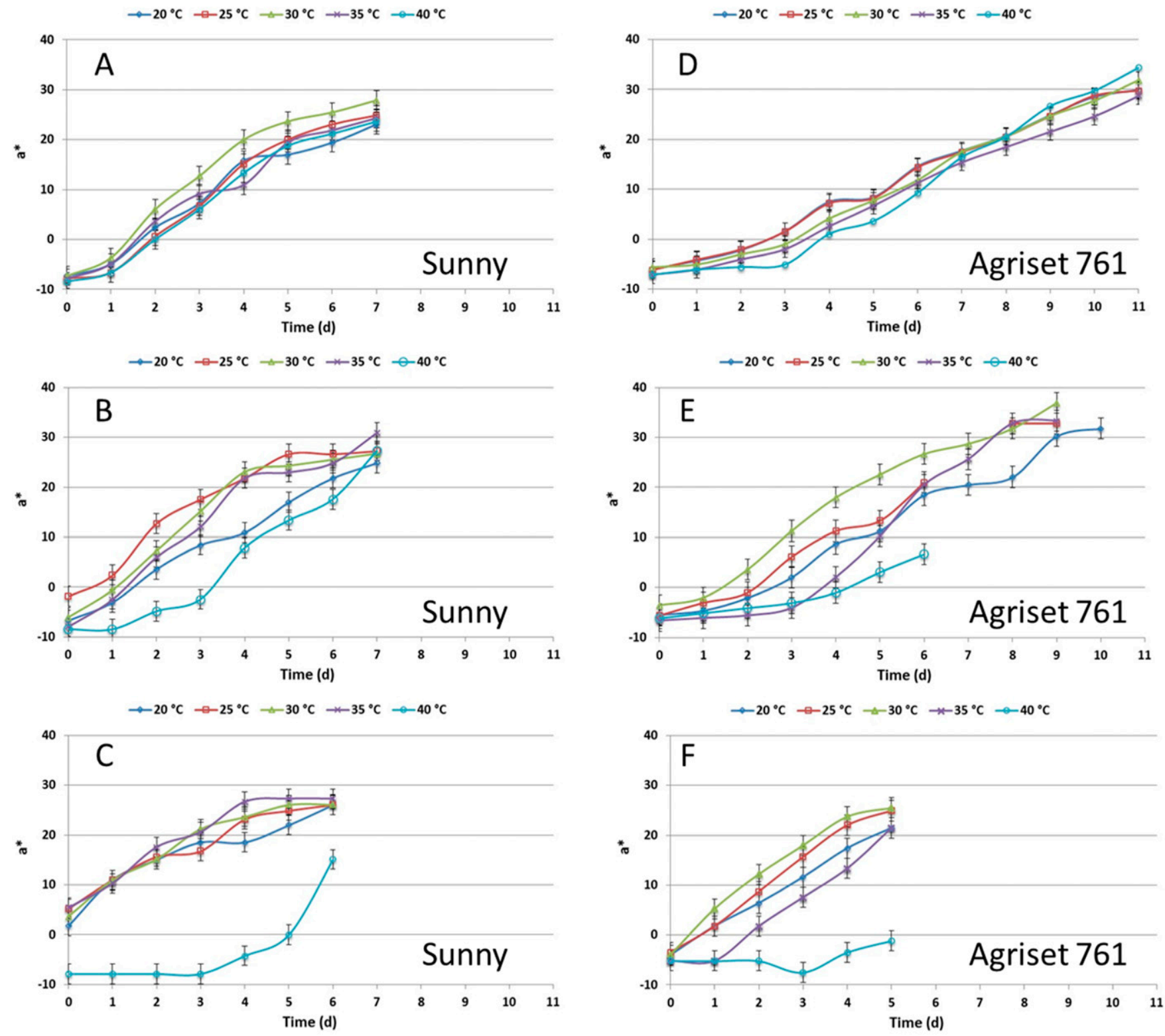

Fig. 3. The a* color value of the epidermis of 'Sunny' and 'Agriset $761^{\prime}$ ' tomatoes during storage at $20{ }^{\circ} \mathrm{C}$ after exposure to 100 $\operatorname{ppm}\left(\mu \mathrm{L} \cdot \mathrm{L}^{-1}\right)$ ethylene at $20,25,30,35$, or $40{ }^{\circ} \mathrm{C}$ for $24 \mathrm{~h}(\mathrm{~A}-\mathrm{D}), 48 \mathrm{~h}(\mathrm{~B}-\mathrm{E})$, or $72 \mathrm{~h}(\mathrm{C}-\mathrm{F})$. Error bars represent the SE within treatments for each exposure time. $\mathrm{SE}=\frac{\mathrm{s}}{\sqrt{\mathbf{n}}}$, where $\mathrm{s}$ is the $\mathrm{SD}$, and $\mathbf{n}$ is the sample size; $\left(1.8 \times{ }^{\circ} \mathrm{C}\right)+32={ }^{\circ} \mathrm{F}$.

Table 1. Analysis of variance of the effect of time and temperature on the quality attributes of 'Sunny' tomatoes treated with $100 \mathrm{ppm}$ ethylene at $20,30,35$, or $40{ }^{\circ} \mathrm{C}$ for 24,48 , or $72 \mathrm{~h}$ then transferred to air at $20{ }^{\circ} \mathrm{C}$ for 11,10 , or $9 \mathrm{~d}$, respectively. ${ }^{\mathrm{z}}$

\begin{tabular}{lcccc}
\hline Factor & Compression & $\mathrm{pH}$ & Titratable acidity & Total soluble solids \\
\hline Time & 0.4116 & 0.0002 & 0.0130 & 0.0001 \\
Temperature & 0.0001 & 0.0195 & 0.0361 & 0.0004 \\
Interaction & 0.0026 & 0.2147 & 0.0085 & 0.0047
\end{tabular}

${ }^{\mathrm{z}} 1 \mathrm{ppm}=1 \mu \mathrm{L} \cdot \mathrm{L}^{-1},\left(1.8 \times{ }^{\circ} \mathrm{C}\right)+32={ }^{\circ} \mathrm{F}$.

increasing the duration of ethylene treatment beyond $72 \mathrm{~h}$ at $40{ }^{\circ} \mathrm{C}$ resulted in injury to 'Sunny' and 'Agriset 761' tomatoes that was characterized by failure to ripen and development of necrotic, watersoaked spots (data not published).
Furthermore, Atta-Aly and Brecht (1995) and Biggs et al. (1988) also reported heat injury from prolonged exposure of tomato fruit to high temperature (i.e., $40^{\circ} \mathrm{C}$ for $72 \mathrm{~h}$ ), which resulted in fruit showing signs of heat injury and subsequently caused a failure to ripen satisfactorily and to rot (data not shown).

The lag in reaching a peak in ethylene production was associated with the duration of ethylene treatment, with the number of days to peak ethylene production decreasing as the duration of ethylene treatment increased from 24 to $72 \mathrm{~h}$ (Fig. 3). In addition, ethylene treatment for 48 or $72 \mathrm{~h}$ resulted in an accelerated development of red color compared with a 24-h ethylene treatment. This implies that the longer the duration of ethylene treatment at the high temperature, the sooner the ethylene climacteric occurred, and thus the 
Table 2. Quality attributes of 'Sunny' tomatoes treated with $100 \mathrm{ppm}$ ethylene at $20,30,35$, or $40{ }^{\circ} \mathrm{C}$ for 24,48 , or $72 \mathrm{~h}$ then transferred to air at $20^{\circ} \mathrm{C}$ for 11,10 , or $9 \mathrm{~d}$, respectively. ${ }^{\mathrm{z}}$

\begin{tabular}{ccclcc}
\hline Time $(\mathbf{h})$ & Temp $\left({ }^{\circ} \mathbf{C}\right)^{\mathrm{z}}$ & Compression $(\mathbf{m m})^{\mathrm{z}}$ & $\mathrm{pH}$ & Titratable acidity (\%) & Total soluble solids (\%) \\
\hline 24 & 20 & $7.13 \mathrm{ef}$ & $3.95 \mathrm{~d}$ & $1.09 \mathrm{bc}$ & $4.36 \mathrm{c}$ \\
& 30 & $9.47 \mathrm{ab}$ & $3.93 \mathrm{de}$ & $0.99 \mathrm{e}$ & $4.70 \mathrm{a}$ \\
& 35 & $6.46 \mathrm{fg}$ & $3.83 \mathrm{ef}$ & $1.06 \mathrm{bcde}$ & $4.67 \mathrm{ab}$ \\
48 & 40 & $8.53 \mathrm{bcd}$ & $3.80 \mathrm{f}$ & $1.07 \mathrm{bcde}$ & $4.70 \mathrm{a}$ \\
& 20 & $7.67 \mathrm{~d}$ & $4.16 \mathrm{~b}$ & $1.08 \mathrm{bcd}$ & $4.73 \mathrm{a}$ \\
& 30 & $8.93 \mathrm{bc}$ & $3.93 \mathrm{~d}$ & $1.36 \mathrm{a}$ & $4.13 \mathrm{~d}$ \\
72 & 35 & $8.13 \mathrm{~cd}$ & $4.10 \mathrm{bc}$ & $1.03 \mathrm{cde}$ & $4.23 \mathrm{c}$ \\
& 40 & $5.07 \mathrm{~h}$ & $4.07 \mathrm{bc}$ & $1.14 \mathrm{~b}$ & $4.13 \mathrm{~d}$ \\
& 20 & $8.13 \mathrm{cde}$ & $4.28 \mathrm{a}$ & $1.03 \mathrm{cde}$ & $4.30 \mathrm{c}$ \\
& 30 & $10.27 \mathrm{a}$ & $4.08 \mathrm{bc}$ & $1.10 \mathrm{bc}$ & $4.57 \mathrm{a}$ \\
& 35 & $5.73 \mathrm{gh}$ & $4.00 \mathrm{~cd}$ & $1.00 \mathrm{de}$ & $4.10 \mathrm{~d}$ \\
\hline
\end{tabular}

${ }^{\mathrm{z}} 1 \mathrm{ppm}=1 \mu \mathrm{L} \cdot \mathrm{L}^{-1},\left(1.8 \times{ }^{\circ} \mathrm{C}\right)+32={ }^{\circ} \mathrm{F}, 1 \mathrm{~mm}=0.0394$ inch.

'Different letters in a column indicate significant differences at $P \leq 0.05$ by the least square difference (LSD) test. The LSD was calculated using the mean sum of squares of the interaction $(\mathrm{MSI})$ using the following formula: $L S D=t_{\left(\frac{0.05}{2}, D G I\right)} \sqrt{\frac{M S I}{\left(\frac{1}{n_{a}}+\frac{1}{n_{b}}\right)}}$, where DGI is the df of the interaction $($ DGI $=6)$, $\mathrm{n}_{\mathrm{a}}$ is the sample size of one treatment $\left(\mathrm{n}_{\mathrm{a}}=3\right)$, and $\mathrm{n}_{\mathrm{b}}$ is the sample size of the other treatment $\left(\mathrm{n}_{\mathrm{b}}=3\right)$.

shorter the time to complete ripening. Similarly, Lagunes et al. (2007) studied the production of ethylene in storage after the application of different doses of exogenous ethylene to unripe mangoes (Mangifera ind$i c a)$; this study revealed that not only duration but also higher concentration of exogenous ethylene treatment induced greater production of ethylene during the subsequent ripening.

Typically, ethylene production follows the same pattern of enzymatic activity of ACC synthase and ACO (Hong et al., 2004; Lagunes et al., 2007; Nakatsuka et al., 1997), although we did not observe a clear correlation between ethylene production and ACO activity in this study. Dong et al. (1992) explained that this discrepancy could be due to the difference between using an in vivo assay vs. in vitro assays; the latter method includes extraction and purification procedures that were used by Hong et al. (2004), Lagunes et al. (2007), and Nakatsuka et al. (1997).

Considering that the synthesis of lycopene in tomatoes requires ethylene (Su et al., 2015), tomato ripening and color uniformity have been shown to be enhanced by ethylene treatment at 20 to $24{ }^{\circ} \mathrm{C}$ in many previous studies (Salveit, 2016). Our study and research by Yakir et al. (1984) show that ethylene treatment at $35^{\circ} \mathrm{C}$ can also evoke faster and more uniform color development, but only after transferring the fruit to $20^{\circ} \mathrm{C}$. In both studies, tomatoes treated with ethylene at 20 or $35^{\circ} \mathrm{C}$ eventually reached similar color intensity and tone independent of the temperature of the applied ethylene treatment.

Flesh firmness was affected by the high-temperature ethylene treatment of MG tomatoes. The firmest fruit were produced by ethylene treatment at $40{ }^{\circ} \mathrm{C}$, followed by 35 and $20^{\circ} \mathrm{C}$; the least firm fruit were those treated with ethylene at $30{ }^{\circ} \mathrm{C}$. In this case, it has been reported that high temperatures $>35{ }^{\circ} \mathrm{C}$ slowed down degradation of the cell wall, probably due to partial inhibition of the activity of polygacturonase (Kagan-Zur et al., 1995; Lurie et al., 1996; Picton and Grierson, 1988). These findings are similar to those of Mitcham and McDonald (1992), who found that softening was inhibited in heated tomatoes (fruit exposed to $40^{\circ} \mathrm{C}$ for $4 \mathrm{~d}$ ). The difference with the present study is that in their experiment, they did not treat fruit with ethylene while at the high temperature.

There were only minor differences in the composition of tomato fruit caused by ethylene treatment at $20,30,35$, or $40^{\circ} \mathrm{C}$ for 24,48 , or 72 h. The only notable difference was that TA was much lower in tomatoes treated with ethylene at 30 to $40{ }^{\circ} \mathrm{C}$ than at $20{ }^{\circ} \mathrm{C}$, which is probably explained by differences in respiration rates with organic acids primarily used as substrate. It can also be noted that TA values of 'Sunny' tomatoes were particularly high but consistent with values reported by Baldwin et al. (1991) for this cultivar.

\section{Conclusions}

We conclude that tomatoes are able to perceive ethylene at high temperatures despite various aspects of ripening being inhibited while the fruit are at the same high temperatures. Ripening is subsequently initiated when the fruit are transferred to air at the ripening-conducive temperature of $20{ }^{\circ} \mathrm{C}$ and the tomato fruit actually ripen faster when treated with ethylene at 30 or $35^{\circ} \mathrm{C}$ compared with fruit that are both treated with ethylene and ripened continuously at $20^{\circ} \mathrm{C}$.

However, the effect of ethylene treatment at high temperature has limitations because fruit that were treated with ethylene at $40{ }^{\circ} \mathrm{C}$ for 48 or $72 \mathrm{~h}$ did not overcome the impairment of normal fruit function due to high temperature injury and hence were unable to normally ripen when transferred to $20^{\circ} \mathrm{C}$; however, a shorter exposure to ethylene at $40^{\circ} \mathrm{C}$ (i.e., 24 h) was not long enough to irreversibly inhibit ripening.

As a practical matter, it can be recommended based on this research that the temperature of MG tomatoes at harvest should be considered when applying ethylene treatment to promote ripening because fruit treated with ethylene at $>35^{\circ} \mathrm{C}$ may exhibit, delayed or even inhibited ripening. Tomatoes should therefore be cooled to at least $35{ }^{\circ} \mathrm{C}$ before ethylene treatment, but further cooling of tomatoes to $\leq 25^{\circ} \mathrm{C}$ could actually result in slower and less uniform ripening.

\section{Literature cited}

AOAC International. 1995. Official methods of analysis of AOAC International. AOAC Intl., Arlington, VA. 
Atta-Aly, M.A. 1992. Effect of high temperature on ethylene biosynthesis by tomato fruit. Postharvest Biol. Technol. 2:19-24, doi: 10.1016/0925-5214(92)90023-I.

Atta-Aly, M.A. and J.K. Brecht. 1995. Effect of postharvest high temperature on tomato fruit ripening and quality, p. 250256. In: A. Ait-Oubahou and M. El-Otmani (eds.). Postharvest physiology, pathology and technologies for horticultural commodities: Recent advances. Hassan II Inst. Agron. Veterinary Med., Agadir, Morocco.

Baldwin, E.A., M.O. Nisperos-Carriedo, R. Baker, and J.W. Scott. 1991. Quantitative analysis of flavor parameters in six Florida tomato cultivars (Lycopersicon esculentum Mill.). J. Agr. Food Chem. 39:11351140, doi: 10.1021/jf00006a029.

Biggs, M.S., W.R. Woodson, and A.K. Handa. 1988. Biochemical basis of hightemperature inhibition of ethylene biosynthesis in ripening tomato fruits. Physiol. Plant. 72:572-578, doi: 10.1111/j.13993054.1988.tb09167.x.

Botella, M.A., F. Del Amor, A. Amoros, M. Serrano, V. Martinez, and A. Cerda. 2000. Polyamine, ethylene and other physico-chemical parameters in tomato (Lycopersicon esculentum) fruits as affected by salinity. Physiol. Plant. 109:428-434, doi: 10.1034/j.1399-3054.2000.100409.x.

Cheng, T.S., J.D. Floros, R.L. Shewfelt, and C.J. Chang. 1988. The effect of hightemperature stress on ripening of tomatoes (Lycopersicon esculentum). J. Plant Physiol. 132:459-464, doi: 10.1016/ S0176-1617(88)80063-4.

Dong, J.G., J.C. Fernández-Maculet, and S.F. Yang. 1992. Purification and characterization of 1-aminocyclopropane-1carboxylate oxidase from apple fruit. Proc. Natl. Acad. Sci. USA 89:9789-9793, doi: 10.1073/pnas.89.20.9789.

Freeman, J.H., E.J. McAvoy, N.S. Boyd, R. Kanissery, H.A. Smith, J. Desaeger, J.W. Noling, and G.E. Vallad. 2019. Tomato production, p. 411. In: P.J. Dittmar, J.H. Freeman, M.L. Paret, and H.A. Smith (eds.). Vegetable production handbook of Florida. 2019-2020 ed. Univ. Florida, Inst. Food Agr. Sci., Gainesville.

Gull, D.D. 1987. A simplified firmness tester for horticultural products. HortScience 22:1146.

Hamson, A.R. 1952. Measuring firmness of tomatoes in a breeding program. Proc. Amer. Soc. Hort. Sci. 60:425-433.

Hobson, G.E., P. Adams, and T.J. Dixon. 1983. Assessing the colour of tomato fruit during ripening. J. Sci. Food Agr. 34:286292, doi: 10.1002/jsfa.2740340312.
Hoffman, N.E. and S.F. Yang. 1982. Enhancement of wound-induced ethylene synthesis by ethylene in preclimacteric cantaloupe. Plant Physiol. 69:317-322, doi: 10.1104/pp.69.2.317.

Hong, J.H., A.K. Cowan, and S. Koo Lee. 2004. Glucose inhibits ACC oxidase activity and ethylene biosynthesis in ripening tomato fruit. Plant Growth Regulat. 43:81-87, doi: 10.1023/B:GROW.0000038248.54232.6a.

Inaba, M. and K. Chachin. 1989. Hightemperature stress and mitochondrial activity of harvested mature-green tomatoes. J. Amer. Soc. Hort. Sci. 1 14:809-814.

Iwahashi, Y., A.K. Horigane, K. Yoza, T. Nagata, and H. Hosoda. 1999. The study of heat stress in tomato fruits by NMR microimaging. Magn. Reson. Imaging 17:767-772, doi: 10.1016/S0730-725X(98) 00219-7.

Kagan-Zur, V., D.M. Tieman, S.J. Marlow, and A.K. Handa. 1995. Differential regulation of polygalacturonase and pectin methylesterase gene expression during and after heat stress in ripening tomato (Lycopersicon esculentum Mill.) fruits. Plant Mol. Biol. 29:1101-1110, doi: 10.1007/BF00020455.

Lagunes, L., B. Tovar, M. Mata, J.C. Vinay-Vadillo, J. De La Cruz, and H.S. Garcia. 2007. Effect of exogenous ethylene on ACC content and ACC oxidase activity during ripening of Manila mangoes subjected to hot water treatment. Plant Foods Hum. Nutr. 62:157163, doi: 10.1007/s11130-007-0057-5.

Lurie, S., H. Alex, F. Elazar, and R. Shapira. 1996. Reversible inhibition of tomato fruit gene expression at high temperature: Effects on tomato fruit ripening. Plant Physiol. 110:1207-1214.

Lurie, S., M. Laamim, Z. Lapsker, and E. Fallik. 1997. Heat treatment to decrease chilling injury in tomato fruit. Effects on lipids, pericarp lesions and fungal growth. Physiol. Plant. 100:297-302, doi: 10.1111/j.1399-3054.1997.tb04786.x.

Maezawa, S., H. Yamada, and K. Akimoto. 1993. Postharvest yellowing of tomato 'Momotaro' as a function of maturity and ripening temperature. J. Jpn. Soc. Hort. Sci. 62:647-653.

Mitcham, E.J. and R.E. McDonald. 1992. Effect of high temperature on cell wall modifications associated with tomato fruit ripening. Postharvest Biol. Technol. 1:257-264, doi: 10.1016/0925-5214(92)90008-d.

Mohammed, M., L.A. Wilson, and P.I. Gomes. 1996. Influence of high temperature stress on postharvest quality of processing and non-processing tomato cultivars. J. Food Qual. 19:41-55, doi: $10.1111 /$ j.1745-4557.1996.tb00404.x.
Nakatsuka, A., S. Shiomi, Y. Kubo, and A. Inaba. 1997. Expression and internal feedback regulation of acc synthase and acc oxidase genes in ripening tomato fruit. Plant Cell Physiol. 38:1103-1110, doi: 10.1093/oxfordjournals.pcp.a029094.

National Oceanic and Atmospheric Administration. 2020. Data tools: Local climatological data. 15 Jan. 2020. <https:// www.ncdc.noa . gov / cdo-web/ datatools $/ \mathrm{lcd}>$.

Picton, S. and D. Grierson. 1988. Inhibition of expression of tomato-ripening genes at high temperature. Plant Cell Environ. 11:265-272, doi: 10.1111/ j.1365-3040.1988.tb01145.x.

Polenta, G., C. Lucangeli, C. Budde, C.B. Gonzalez, and R. Murray. 2006. Heat and anaerobic treatments affected physiological and biochemical parameters in tomato fruits. Lebensm. Wiss. Technol. 39:27-34, doi: 10.1016/j.lwt.2004.11.003.

Salveit, M.E. 2016. Ethylene effects, p. 76-82. In: K.C. Gross, C.Y. Wang, and M. Saltveit (eds.). The commercial storage of fruits, vegetables, and florist and nursery stocks. U.S. Dept. Agr., Washington, DC.

Sargent, S.A. and C.L. Moretti. 2016. Tomato, p. 581-587. In: K.C. Gross, C.Y. Wang, and M. Saltveit (eds.). The commercial storage of fruits, vegetables, and florist and nursery stocks. U.S. Dept. Agr., Washington, DC.

Su, L., G. Diretto, E. Purgatto, S. Danoun, M. Zouine, Z. Li, J.P. Roustan, M. Bouzayen, G. Giuliano, and C. Chervin. 2015. Carotenoid accumulation during tomato fruit ripening is modulated by the auxinethylene balance. BMC Plant Biol. 15:114, doi: 10.1186/s12870-015-0495-4.

U.S. Department of Agriculture. 1991. United States standards for grades of fresh tomatoes. U.S. Dept. Agr., Washington, DC.

Yakir, D., A. Sadovski, H.D. Rabinowitch, and J. Rudich. 1984. Effect of high temperature on quality of processing-tomatoes of various genotypes ripened off the vine. Scientia Hort. 23:323-330, doi: 10.1016/0304-4238(84)90028-1.

Yang, R.F., T.S. Cheng, and R.L. Shewfelt. 1990. The effect of high temperature and ethylene treatment on the ripening of tomatoes. J. Plant Physiol. 136:368-372, doi: 10.1016/S0176-1617(11)80064-7.

Zhou, B., Y. Luo, E.R. Turner, Q. Wang, and K.R. Schneider. 2014. Evaluation of current industry practices for maintaining tomato dump tank water quality during packinghouse operations. J. Food Process. Preserv. 38:2201-2208, doi: 10.1111/ jfpp. 12200. 